\title{
A Feasibility Study of
}

\section{Part Time Day and Evening Classes}

in the Nursing Science Department of the L Liversity of Zululand

\author{
D Nzimakwe \\ Ph D \\ Community Health Nursing Science \\ University of Zululand \\ Durban- Umlazi Campus
}

\section{Abstract}

The study determines the practising professional nurses including those in the nursing colleges who would enrol if part time studies were introduced at the University of Zululand in 1991.

Questionnaires were sent to various institutions in KwaZulu-Natal.

Four hundred and fourty eight (448) nurses responded positively to the questionnaire which was an indication that if such studies were introduced many nurses would enrol.

The study reveals the enthusiasm and action taken by a nurse who is working and attending classes part time.

\section{Opsomming}

Die ondersoek bepaal die praktiserende professionele verpleegsters, insluitende diegene in die verpleegsterskolleges, wat sal registreer indien deeltydse studies in 1991 by die Universiteit van Zoeloeland ingestel sou word. Vraelyste is aan verskeie instellings in KwaZulu-Natal gestuur. Vier honderd agt en veertig verpleegsters het positief op die vraelys gereageer, wat ' $n$ aanduiding is dat indien sodanige studies wel aangebied word, 'n groot aantal verpleegsters sal registreer. Die ondersoek het getoon dat daar entoesiasme is vir so ' $n$ stap by verpleegsters wat voltyds werk en graag lesings deeltyds wil bywoon.

\section{Introduction}

The occurrence of strange diseases and infections, the technical developments in health care and the sudden realisation of human rights have been instrumental in introducing changes in the delivery of health care by nurses. This change has increased the need for a skilled and well prepared nurse who is a graduate and who engages in both in-service and continuing education programmes to keep abreast with these developments. A nurse that does not realise that nursing is dynamic and does not keep abreast with developments and change becomes lost in the profession and cannot contribute significantly to patient care. The nursing colleges offer training at four year diploma level but the universities still play a major role in preparing nurses at graduate and post graduate levels. The researcher in this study explores the feasibility of introducing part time classes at the University of Zululand main campus and the Durban-Umlazi Campus. The terms that will be used frequently in this report are defined.

\section{Definition of Terms}

Part is defined by the oxford English Dictionary as something less than a whole.

\section{Part time}

Part time is part of time less than that of normal full time lectures. It also means part of time that is spent for lectures while students are engaged in any form of employment. Day Classes

Day classes are offered to full time students starting from $09 \mathrm{~h} 15$ to 17 h45 in the University of Zululand.

\section{Part time evening classes}

Part time evening classes are conducted on daily basis from $16 \mathrm{~h} 30$ and run up to 21h45. These classes are convenient to students who work a straight shift $8-4 \mathrm{p} . \mathrm{m}$. such as teachers.

Part time day classes

Part time day classes are conducted on day release basis for the University of Zululand. Students are required to request a day once a week to attend classes which are 
conducted throughout the day. Students who are employed and work night shift such as nurses benefit from the day release method of offering lectures.

\section{Catchment Area}

A catchment area is a designated area chosen by the researcher to undertake research.

The catchment area for this study included all the regions in the KwaZuluNatal Province. Hospitals, Technikons, Universities including training colleges for nurses were used for research.

\section{Background of the Study}

The researcher being a registered nurse and lecturer at the University of Zululand often heard nurses expressing their willingness to study if lectures were offered on part-time bases during the day or during the night. Concern was caused by availability of lectures only to full-time students which forced practising registered - Nurses to resign from their places of employment or be granted unpaid study leave. Nurses who were willing to resign to study with the university did so but the conditions were unsuitable. The researcher therefore saw the need for the university to initiate parttime day or night classes at the university of Zululand. An investigation therefore became necessary to explore the number of nurses who would be willing to attend such part-time classes if they were introduced.

\section{Statement Of The Problem}

Nurses registering for undergraduate and postgraduate studies at the University of Zululand were only admitted as full time students before 1991. The status quo then presented problems as nurses had to resign from their institutions, a situation which interfered with their economic status. Most of the nurses who would register for under graduate and post graduate courses were demotivated to do so due to economic constraints

\section{Aim of the Study}

The aim of the study is to establish if practising professional nurses would be interested to enrol if part time studies could be introduced in the University of Zululand in 1991 and 1992 and to determine if nurses in this region were studying to ascertain their level of motivation and the likelihood of the programme being supported.

\section{Objectives of the Stuidy}

- To bring to the awareness of the public the role that the University of Zululand would play in the upliftment and empowerment of nurses who trained some years back, who need to achieve knowledge and skills while being employed on full time basis.

-

To motivate for academic pursuit among the nurses and determine if the service will be utilized.

\section{- $\quad$ To develop strategies towards} initiating part time day and evening classes in the university of Zululand.

\section{Methodology}

A descriptive survey was conducted to explore the reaction of nurses to availability of part time nursing courses at the university. A questionnaire consisting of 6 items was sent to 49 hospitals in KwaZulu-Natal. Items in the questionnaire consisted of:

1. The university, college or technikon through which studies were undertaken, if respondent was on a programme of self development.

2. The courses undertaken or intended diploma, including the degree that the respondent was doing.

3. Major subjects that were undertaken. 4. Time when the courses would be completed.

5. Indication if the respondent would start or pursue studies in 1993.

6. The courses the respondent intended to do.

\section{Sending of Questionaires}

A letter requesting participation of the registered nurses in the study was written to the matron and superintendent of each hospital. Emphasis was made that participation was voluntary and participants were to give consent to participate in the study. Instructions were given to participants on the questionnaire indicating that anonymity would be preserved and no names were to be used. A total of 20 questionnaires was sent to each institution and in all 980 questionnaires were sent to these institutions. The matron of each hospital disseminated information and questionnaires to the registered nurses. Nurses responded to these questionnaires although in some hospitals there was no response. A sum of 547 questionnaire was received from the respondents and a response rate of $56 \%$ was obtained.

\section{Selection of a sample}

A sample constituted of registered male and female nurses working in hospitals within the KwaZulu-Natal Province. A convenience sample was used as only those nurses who responded to the questionnaire formed sample for the study. These nurses were currently studying at technikons and nursing colleges, some were undergraduate and post-graduate students including those who were not studying.

\section{Delimitation of the Sturdy}

The study was conducted in KwaZuluNatal Province and was confined to practising professional nurses who were currently not studying, and those who were undergraduates, post graduates at Universities including those nurses who were studying with technikons and nursing colleges.

\section{Limitations of the Study}

- There was general delay in returning the questionnaire which may be ascribed to the Christmas season that was approaching.

- Some institutions did not return the questionnaire.

- Institutions returned correctly filled in while some were incorrectly filled.

- Some respondents did not indicate whether studying or not studying or when enrolment was desired.

- There was frequent misinterpretation of questions in the questionnaire.

- There was reluctance to respond attributed to a previous similar research which was undertaken by the Nursing Science Department of the University and there was no action taken thereafter due to some financial implication.

\section{Data Analysis}

To make data analysis possible, items were listed and the number of responses against these items were counted and a sum total was arrived at. The figures determined whether the topic was chosen by respondent or not.

1. No of persons who responded to the questionnaire $=547$

2. No of students registered with UNISA $=294$

3. No of students registered with Natal University $=17$

4. No of students at Technikons $=\mathbf{4 6}$

5. No of students at University of Zululand $=30$

6. No of students at Colleges $=\mathbf{4 5}$

7. No of persons not studying $=115$

8. Total $=547$ 
The responses to the questionnaire revealed that nurses who were presently studying and those who were not studying would be equally interested to enrol with the university of Zululand if this programme was introduced

\section{Findings of the Study}

- The highest figure was that of professional nurses who were interested in registering for the $B$. Cur $E$ et $A$ degree followed by those that were interested in post graduate studies and the lowest figures were for those nurses who were interested in Diploma courses.

- $\quad$ From the study, it is obvious that nurses are a motivated group generally with a high percentage studying privately at UNISA, the majority of which have indicated the intention of pursuing or finishing off with University of Zululand.

- The number of nurses that were not studying and those that were in Colleges of Education and Technikons who had responded and indicated that they would be interested to study was high enough to envisage success in enrolling students for the nursing courses at the University of Zululand in the near future.

- - From the results of the study, it is deduced that students automatically continue studying $B$. Cur after basic diploma course, diploma in midwifery, diploma in primary health care and diploma in community health which will generally improve the quality of students who enrol with this department. Students who studied on part time bases with UNISA and technikons were in the

\section{Tablel}

Determines number of students who were styding with tertiary institutions.

\begin{tabular}{|c|c|c|c|c|c|}
\hline $\begin{array}{c}\text { UNIVERSITY OF } \\
\text { SOUTH AFRICA }\end{array}$ & TECHNIKONS & $\begin{array}{c}\text { COLLEGES OF } \\
\text { NURSING }\end{array}$ & $\begin{array}{c}\text { UNIVERSITY OF } \\
\text { ZULULAND }\end{array}$ & $\begin{array}{c}\text { NATAL } \\
\text { UNIVERSITY }\end{array}$ & $\begin{array}{c}\text { NO. OF PEOPLE } \\
\text { NOT STUDYING }\end{array}$ \\
\hline 1 & 2 & 3 & 4 & 5 & 115 \\
\hline 294 & 46 & 45 & 30 & 17 & 547 \\
\hline
\end{tabular}

The total number of nurses who were studying was 432 when 115 nurses were not studying but would register if part time courses were introduced. This was also an indication of what type of student the university would expect if part courses were introduced.

\section{Table 2}

Determines carses that were currently undertaken by the nurses.

The table excludes 115 nurses who were not studying

\begin{tabular}{|c|c|c|c|c|c|c|}
\hline $\begin{array}{c}\text { DIPLOMA } \\
\text { MIDWIFER }\end{array}$ & $\begin{array}{c}\text { B.CUR } \\
\text { DEGREE }\end{array}$ & $\begin{array}{c}\text { DIPLOMA } \\
\text { COMM } \\
\text { HEALTH }\end{array}$ & $\begin{array}{c}\text { DIPLOMA } \\
\text { PRIMARY } \\
\text { HEALTH CARE }\end{array}$ & $\begin{array}{c}\text { DIPLOMA } \\
\text { NURSING } \\
\text { ADMIN }\end{array}$ & $\begin{array}{c}\text { DIPLOMA } \\
\text { NURSING } \\
\text { EDUCATION }\end{array}$ & $\begin{array}{c}\text { HONOURS } \\
\text { DEGREE }\end{array}$ \\
\hline 1 & 2 & 3 & 4 & 5 & 6 & 7 \\
\hline 186 & 182 & 30 & 14 & 10 & 8 & 2 \\
\hline
\end{tabular}

Table two shows that out of 432 nurses who were currently studying only 182 were enrolled for a B. Cur degree and the rest were registered with Technikons, nursing colleges or universities but undertaking Diploma courses which was a strength for this project to be initiated. The number of nurses who wished to persue with studies and on part time bases and including those nurses who were not studying commence studies were 418 . Persons who did not wish to be involved in part time studies were only 14.

\section{Table 3}

Determines the carses that would be undertaken if part time courses are avalable

\begin{tabular}{|c|c|c|c|c|c|c|}
\hline $\begin{array}{c}\text { B.CUR } \\
\text { DEGREE }\end{array}$ & $\begin{array}{c}\text { HONOURS } \\
\text { DEGREE }\end{array}$ & $\begin{array}{c}\text { DIPLOMA } \\
\text { COMM } \\
\text { HEALTH }\end{array}$ & DNA & DNE & $\begin{array}{c}\text { DOCTORAL } \\
\text { DEGREE }\end{array}$ & $\begin{array}{c}\text { DIPLOMA } \\
\text { PRIMARY } \\
\text { HEALTH CARE }\end{array}$ \\
\hline 1 & 2 & 3 & 4 & 5 & 6 & 7 \\
\hline 368 & 42 & 13 & 10 & 10 & 3 & 2 \\
\hline
\end{tabular}


majority which shows the preparedness of nurses for part time studies.

- Respondents from Pietermaritzburg and surrounding areas were the lowest as - only 11 nurses responded.

- The highest number of nurses who were prepared to register for the year 1991 was 304 . This is an indication for a high level of motivation and enthusiasm among the nurses which is a positive sign that the service is needed.

\section{Recommendations}

The highest percentage of positive responses came from the Durban area and surroundings. This made the Durban-Umlazi Campus be targeted for part time studies for the nursing science department. This campus did not offer nursing courses during this time.

The following recommendations were made:

1. Part time and evening classes should be made available at the main campus of the University of Zululand and the Durban-Umlazi Campus as soon as possible.

2. Employment of additional lecturers would have to be considered to deal with extra load of work and selected subjects by respondents were to be made available if possible. The department of nursing consisted of 14 members of the staff. Two Professors and 12 lecturers. Courses offered were Basic B.Cur Courses, Post Basic undergraduate and post-graduate courses.

3. The possibility of introducing decentralized training programmes was to be

explored.

\section{Condusion}

The study showed interesting relationship between the level of motivation of nurse professionals who were studying degree and diploma courses than those who were not studying as they were prepared to commence undergraduate or post graduate studies should part time studies be introduced. A diploma or degree course attained by the student has been seen in this study as a factor that motivated subjects to continue studying. From the study it 15 deduced that respondents are in favour of being guided and supervised by lecturers. The system of evening classes and part time lectures is likely to motivate even the less motivated subjects as contact with lecturers will be established and maintained.

\section{Outcome of the Study}

The University of Zululand officials considered initiating part time courses at Durban- Umlazi Campus.

NB: A further publication on the implementation of this research is to follow.

\section{Bibliography}

ANDREWS Y. 1982. Medical Practitioners and Nursing Professionals As Public Administrators. PRETORIA: Haum Educational Publishers.

BANDMAN, E.L. and BANDMAN, B. 1995. Nursing Ethos Through Lifespan. Connecticut: Appleton and Lange.

BOOYENS, S.W. 1993. Nursing Management CAPE TOWN: Juts \& Co. LTD.

BRYANT, J. 1984. From Alma Ata to the year 2000

GENEVA: World Health Organization.

CLARK, M.J. 1994. Community Nursing Health Care Today and Tomorrow. GREAT BRITAIN : Reston Publishing Co.

DE HAAN M. 1994 6th AD. The Health of Southern Africa CAPE TOWN: Juta and CO.LTD.

DENNIL, K. KING,M. AND SWANEPOEL,T. 1995. Aspects of Primary Health Care. Halfway House: Sothern South Africa. Book Publisher

DIANAN, M.B.K. 1985. Promoting Health: A Practical Guide to Health Education. PHILADELPHIA: Lea and Feliger USA.

DREYER, A.J. AND DUMINY P.A. 1998. A Course In Psychopedagogics CAPE TOWN: Maskew Miller.

DREYER M. HATTING,S. AND LOCK, M. 1993. Fundamental Aspects In Community Health Nursing. Halfway House Southern Book Publisher. South Africa.

SEAMAN, C.H.C. 1987. 3rd Research Methods Principles, Practice And Theory for Nursing. Carlifonia:Appleton and Lange. 